\title{
The Effect of 2D(2R) Substitution on the Agronomical Traits of Winter Triticale in Early Generations of Two Connected Crosses
}

\author{
M.S. Bazhenov*, M.G. Divashuk, P.Yu. Kroupin, V.V. Pylnev and G.I. Karlov \\ Centre for Molecular Biotechnology, Russian State Agrarian University - Moscow Timiryazev Agricultural \\ Academy, Timiryazevskaya St. 49, Moscow, 127550 Russia
}

(Received 14 June 2014; Accepted 24 September 2014; Communicated by L. Bona)

\begin{abstract}
The association between genomic constitution and agronomic traits was studied in $\mathrm{F}_{2}$ plants and $\mathrm{F}_{3: 4}$ families of two crosses between a winter hexaploid triticale line with a $2 \mathrm{D}(2 \mathrm{R})$ chromosome substitution and two hexaploid triticale cultivars carrying the complete rye genome (BBAARR). The analyses revealed that $2 \mathrm{D}(2 \mathrm{R})$ substitution reduces plant height and spikelet number per spike, increases the 1,000-kernel weight, does not reduce grain shrivelling, and promotes early heading and anthesis. 2D(2R) substitution lines exhibit deeper postharvest seed dormancy, which provides resistance to preharvest sprouting. However, 2D(2R) substitution lines are not recommended for winter hexaploid triticale cultivar development purposes due to their reduced grain productivity.
\end{abstract}

Keywords: Triticosecale, chromosome substitution, plant height, grain shrivelling, preharvest sprouting

Abbreviations: ANOVA - analysis of variance; DNA - deoxyribonucleic acid; GE genotype-environment (interaction); GI - germination index; GNS - grain number per spikelet; GWS - grain weight per spike; MSL - main stem length; PCR - polymerase chain reaction; QTL - quantitative trait locus; SNS - spikelet number per spike; SSR - simple sequence repeat; TBE - Tris-borate-EDTA buffer; UV - ultraviolet

\section{Introduction}

Hexaploid triticale (Triticosecale Wittm., BBAARR, $2 \mathrm{n}=42$ ) is usually grown for feed grain and as a hay or a grazing crop. However, most of the available triticale cultivars are not suitable for human consumption due to their weak gluten strength, preharvest sprouting and shrivelled grain (Mergoum et al. 2009). The incorporation of bread wheat (Triticum aestivum L., BBAADD) D-genome chromosomes into hexaploid triticale might improve some of these agronomical traits (Budak et al. 2004; Sodkiewicz et al. 2011). The $2 \mathrm{D}(2 \mathrm{R})$ substitution is among the most widespread substitutions in spring triticale lines and cultivars (Mergoum et al. 2004; Lapin et al. 2007; Divashuk et al. 2010b; National Research Council 1989).

* Corresponding author; E-mail: mikhabazhenov@gmail.com 
Triticale lines with the $2 \mathrm{D}(2 \mathrm{R})$ substitution tend to mature earlier and are shorter, daylength insensitive and resistant to preharvest sprouting (Rybka 2003; Mergoum et al. 2004; Kurkiev 2008). However, 2D(2R) substitution decreases resistance to stem rust and tolerance to the presence of aluminium ions and to high soil acidity (Royo et al. 1993; Darvey et al. 2000; Kim et al. 2001; Budzianowski and Woś 2004).

Most previous studies on the effects of $2 \mathrm{D}(2 \mathrm{R})$ substitution in hexaploid triticale were performed in backcrossed lines of late generations that were subjected to selection or lines and cultivars with 2D from different sources (Reddy and Zereena 1999; Kim et al. 2001; Rybka 2003; Budak et al. 2004; Budzianowski and Woś 2004; Kurkiev 2008; Gill et al. 2010; Divashuk et al. 2010b). Thus, the study of the effect of 2D(2R) substitution on agronomic traits in early generations of crossing that have not been subjected to selection, is useful for planning breeding strategies.

The $2 \mathrm{R}$ chromosome (the largest chromosome in the rye genome) is eliminated frequently in crosses between hexaploid triticale and bread wheat (Gupta and Priyadarshan 1982). Studies of the meiotic behaviour of $2 \mathrm{D}$ and $2 \mathrm{R}$ in dimonosomic lines of wheat showed no pairing between them (Silkova et al. 2014). The only T2R.2DL translocations found thus far have resulted from ruptures in the centromeric region, which were followed by centric fusion; thus, these events did not involve small chromosome segments (Krasilova et al. 2012).

Due to this finding, $2 \mathrm{D}(2 \mathrm{R})$ substitution can be identified in individual plants using a small number of PCR-based molecular markers that are distributed along the chromosome. Earlier, we successfully used microsatellite markers (SSRs) to identify substitutions and translocations in triticale lines and compared these techniques with traditional cytogenetic methods (Lapin et al. 2007; Divashuk et al. 2010a).

The aim of this study was to examine the effect of $2 \mathrm{D}(2 \mathrm{R})$ substitution on yield components, plant height and seed dormancy in early generations of winter hexaploid triticale crosses.

\section{Materials and Methods}

\section{Plant material}

The plant material used was derived from crosses between three triticale accessions, namely crosses between line 21759/97 and cultivar Fidelio and between 21759/97 and cultivar Alexander. 21759/97, a 2D(2R)-substituted line of hexaploid triticale, was used as a donor of the $2 \mathrm{D}$ chromosome. Fidelio and Alexander are promising triticale cultivars with complete A, B and R genomes. Seventy individual plants from each of the generated $\mathrm{F}_{2}$ populations were randomly sampled and self-pollinated in 2010. Using the results of plant genotyping (described below), $\mathrm{F}_{2}$ plants possessing only $2 \mathrm{D}$ or only $2 \mathrm{R}$ chromosomes were selected. $\mathrm{F}_{3}$ plants grown from seeds obtained from self-pollinated individual plants of $F_{2}$ in 2011 and $F_{4}$ plants grown from seeds obtained from cross-pollinated sib plants of $F_{3}$ in 2012 are referred to as families. The $F_{2}$ populations and the $F_{3}$ and $F_{4}$ 
families derived from the crosses are designated as $F_{2(3,4)}(21759 / 97 \times$ Fidelio $)$ and $\mathrm{F}_{2(3,4)}(21759 / 97 \times$ Alexander $)$.

\section{Growing conditions}

$\mathrm{F}_{2(3,4)}$ plants were grown in field plots at the Russian State Agrarian University - Moscow Agricultural Academy (Moscow) in 2010, 2011 and 2012. $\mathrm{F}_{2}$ populations were grown in $1-\mathrm{m}^{2}$ field plots. $\mathrm{F}_{3}$ and $\mathrm{F}_{4}$ families were sown on single-row plots at 20 seeds per row and at an inter-row spacing of $30 \mathrm{~cm}$.

\section{Agronomical traits}

Spikelet number per spike (SNS), grain number per spikelet (GNS), and spike density were measured in the $\mathrm{F}_{2}$ population using individual randomly sampled plants from each cross. Tilling capacity, main stem length (MSL), SNS, GNS, grain weight per spike (GWS), spike density, and 1,000-kernel weight were measured using ten randomly sampled plants from 42 families of $\mathrm{F}_{3: 4}(21759 / 97 \times$ Alexander $)$ and 53 families of $\mathrm{F}_{3: 4}(21759 / 97 \times$ Fidelio $)$ and were counted as averages for each family. Field emergence and winter survival were calculated using all available plants for each family. The durations of the development stages were recorded for each family as a whole.

Grain plumpness was estimated visually using a four-point scale (poor, satisfactory, good and excellent). Germination index (GI) was estimated for freshly harvested grains in Petri dishes using 20 grains from each $\mathrm{F}_{2}$ plant and two 100-grain samples from the $\mathrm{F}_{3}$ and $\mathrm{F}_{4}$ families. The grains were germinated during 14 days in darkness at $25^{\circ} \mathrm{C}$, and GI was calculated according to the formula:

$$
G I=\frac{14 \times n_{1}+13 \times n_{2}+\ldots+1 \times n_{14}}{D \times N},
$$

where $n_{1}, n_{2}, \ldots, n_{14}$ are the number of grains that had germinated on day 1 , day $2, \ldots$, day 14 , respectively; $N$ is the total number of viable grains; and $D$ is the total number of days. The maximum index is 1.0 if all grains germinate by day 1 , and lower indices indicate higher levels of seed dormancy.

\section{Plant genotyping}

DNA was extracted from the leaves of $F_{2}$ plants according to the protocol described by Bernatzky and Tanksley (1986).

Chromosome 2D was detected using the chromosome-specific PCR-based microsatellite markers (SSRs) Xwmc111 and Xgwm261 for the short arm and Xgwm539 and Xbarc1143 for the long arm (Röder et al. 1998; Somers and Isaac 2004; Song et al. 2005). Chromosome 2R was detected using an STS marker for the Sec2 gene that is located on 2RS (Lee et al. 1994). PCR conditions were optimised in our previous work 
(Lapin et al. 2007). The amplified DNA fragments were subjected to electrophoresis in 1.5 or $2 \%$ agarose gels using TBE buffer at $6 \mathrm{~V} / \mathrm{cm}$ and were visualised by UV transillumination after ethidium bromide staining. The protocol published in Korzun et al. (1998) was used to determine allelic variation for the microsatellite marker Xgwm261, which is linked with Rht8. Fragments of various sizes for Xgwm261 were detected using an ABI3130xl Genetic Analyzer (Applied BioSystems, Foster City, CA).

\section{Statistical analysis}

The effect of $2 \mathrm{D}(2 \mathrm{R})$ substitution was determined by processing the data using one-way and two-way ANOVA. The effects of genotype [2D(2R) substitution], environment and genotype-environment interaction (GE) were estimated using two-way ANOVA. Confidence intervals were calculated using Student's $t$-test. To reveal the association between 2D(2R) substitution and grain plumpness, Fisher's exact test (1934) was used. Statistica 6.0 software and an on-line calculator for Fisher's exact test were used (http://in-silico. net/tools/statistics/fisher_exact_test).

\section{Results}

\section{PCR analysis}

We assumed that the amplification of microsatellite markers for chromosome 2D and no amplification of the STS marker for Sec2 indicate a triticale plant possessing 2D(2R) substitution and vice versa (Fig. 1). If the amplification of markers for both chromosomes was detected, the plant was considered heterozygous, that is, carrying both $2 \mathrm{R}$ and $2 \mathrm{D}$ chromosomes.

The markers distributed along the 2D chromosome were always detected together in the same individuals of the $\mathrm{F}_{2}$ populations. Therefore, it was concluded that there were no large deletions and translocations involving chromosome $2 \mathrm{D}$ in the analyzed plant material. In $\mathrm{F}_{2}(21759 / 97 \times$ Alexander $), 28$ homozygotes and 11 heterozygotes for the $2 \mathrm{D}(2 \mathrm{R})$ substitution were found, and 31 plants did not carry the $2 \mathrm{D}(2 \mathrm{R})$ substitution. In $\mathrm{F}_{2}(21759 / 97 \times$ Fidelio $), 17$ homozygotes and 20 heterozygotes for the $2 \mathrm{D}(2 \mathrm{R})$ substitution

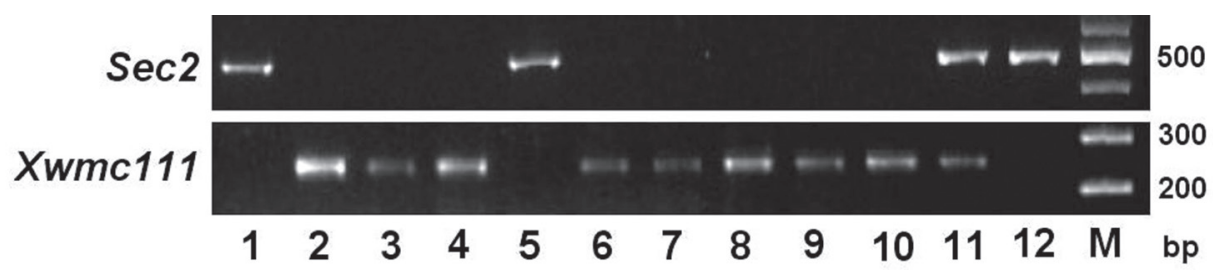

Figure 1. Agarose gel electrophoresis of PCR products of STS marker for Sec2 gene and Xwmc111 microsatellite marker. Lanes indicate the plants in $\mathrm{F}_{2}(21759 / 97 \times$ Alexander $): 2,3,4,6-10$ possess $2 \mathrm{D}(2 \mathrm{R})$-substitution, $1,5,12$ do not have substitution, 11 possess both $2 \mathrm{R}$ and $2 \mathrm{D}$ chromosomes. $\mathrm{M}-100$ bp Plus DNA Ladder, Thermo Scientific 
were revealed, and 33 plants did not carry the $2 \mathrm{D}(2 \mathrm{R})$ substitution. The number of plants having both $2 \mathrm{R}$ and $2 \mathrm{D}$ chromosomes was smaller than expected; that might be due to their lower viability.

Fifteen families with the $2 \mathrm{D}(2 \mathrm{R})$ substitution and 24 without the $2 \mathrm{D}(2 \mathrm{R})$ substitution from $\mathrm{F}_{3: 4}(21759 / 97 \times$ Alexander $)$ and 8 families with the $2 \mathrm{D}(2 \mathrm{R})$ substitution and 33 families without the $2 \mathrm{D}(2 \mathrm{R})$ substitution from $\mathrm{F}_{3: 4}(21759 / 97 \times$ Fidelio $)$ were selected using PCR analysis.

\section{Main stem length}

The difference in MSL between plants with the $2 \mathrm{D}(2 \mathrm{R})$ substitution and plants without the $2 \mathrm{D}(2 \mathrm{R})$ substitution $(\Delta \mathrm{MSL})$ was significant in $\mathrm{F}_{3: 4}(21759 / 97 \times$ Alexander $)$ families: $\triangle$ MSL was $12 \mathrm{~cm}$ in $\mathrm{F}_{3}(21759 / 97 \times$ Alexander) (mean MSL was $84 \mathrm{~cm}$ ) and $25 \mathrm{~cm}$ in $\mathrm{F}_{4}(21759 / 97 \times$ Alexander) (mean MSL was $123 \mathrm{~cm})$ (Table 1). The effects of genotype $(2 \mathrm{D}(2 \mathrm{R})$ substitution), environment and genotype-environment interaction (GE) were estimated using two-way ANOVA. Significant effects of genotype ( $\mathrm{F}=64.5 ; p<0.01)$, environment $(\mathrm{F}=262.8 ; p<0.001)$ and $\mathrm{GE}(\mathrm{F}=7.9 ; p=0.06)$ on plant height were observed. PCR analysis of 21759/97 revealed that this line carries the $165 \mathrm{bp}$ allele of Xgwm261, which is not associated with the Rht8 dwarfing allele.

The difference in MSL between plants with and without the $2 \mathrm{D}(2 \mathrm{R})$ substitution was

Table 1. The effect of $2 \mathrm{D}(2 \mathrm{R})$ substitution on main stem length in $\mathrm{F}_{3}-\mathrm{F}_{4}$ populations

\begin{tabular}{|c|c|c|c|c|}
\hline \multirow{2}{*}{ Cross } & \multirow{2}{*}{ Year } & \multicolumn{2}{|c|}{ Main stem length $^{1}$} & \multirow{2}{*}{ Significance level $^{2}(p)$} \\
\cline { 3 - 5 } & & $\begin{array}{c}\text { with 2D(2R) substitution, } \\
\mathrm{cm}\end{array}$ & without substitution, cm & \\
\hline $21759 / 97 \times$ Alexander & 2011 & $77 \pm 5$ & $89 \pm 5$ & $<0.001$ \\
\cline { 2 - 5 } & 2012 & $108 \pm 7$ & $133 \pm 4$ & $<0.001$ \\
\hline $21759 / 97 \times$ Fidelio & 2011 & $68 \pm 5$ & $75 \pm 4$ & 0.067 \\
\cline { 2 - 5 } & 2012 & $108 \pm 11$ & $127 \pm 4$ & $<0.001$ \\
\hline
\end{tabular}

$195 \%$ confidence intervals are given.

${ }^{2}$ Here and then F-Fisher's test was used for significance level determination.

slightly significant in $\mathrm{F}_{3}(21759 / 97 \times$ Fidelio) $(\triangle \mathrm{MSL}, 7 \mathrm{~cm}$; mean MSL, $73 \mathrm{~cm})$ and was significant in $\mathrm{F}_{4}(21759 / 97 \times$ Fidelio) $(\Delta \mathrm{MSL}, 19 \mathrm{~cm}$; mean MSL, $121 \mathrm{~cm})$. Two-way ANOVA showed that the effects of genotype $(\mathrm{F}=17.9, p<0.001)$ and environment $(\mathrm{F}=216.2 ; p<0.001)$ on plant height were significant but that the effect of $\mathrm{GE}(\mathrm{F}=3.3$; $p=0.07)$ on plant height was insignificant. 


\section{Yield component analysis}

On average, GWS was 2 and 1.5 times lower in $\mathrm{F}_{3: 4}(21759 / 97 \times$ Alexander $)$ and $\mathrm{F}_{3: 4}(21759 / 97 \times$ Fidelio) plants with the $2 \mathrm{D}(2 \mathrm{R})$ substitution than in plants without the $2 \mathrm{D}(2 \mathrm{R})$ substitution (Table 2 ). The observed decrease in GWS is explained primarily by the decrease in SNS and secondarily by the decrease in GNS. Among the 2D(2R) substitution genotypes, SNS consistently decreased from year to year in both studied crosses. Significant decreases in GNS were observed in plants with the $2 \mathrm{D}(2 \mathrm{R})$ substitution in both $\mathrm{F}_{2: 4}(21759 / 97 \times$ Alexander $)$ and $\mathrm{F}_{3}(21759 / 97 \times$ Fidelio $)$.

The value of 1,000-kernel weight was significantly higher in $\mathrm{F}_{3: 4}(21759 / 97 \times$ Alexander $)$ plants with the $2 \mathrm{D}(2 \mathrm{R})$ substitution than in plants without the $2 \mathrm{D}(2 \mathrm{R})$ substitution. In other cases, the effect of the $2 \mathrm{D}(2 \mathrm{R})$ substitution on this trait was insignificant.

Tilling capacity in $\mathrm{F}_{3}(21759 / 97 \times$ Fidelio $)$ and winter survival in $\mathrm{F}_{3: 4}(21759 / 97 \times$ Fidelio $)$ were slightly lower in plants possessing the $2 \mathrm{D}(2 \mathrm{R})$ substitution. Field emergency was slightly lower in $\mathrm{F}_{3: 4}(21759 / 97 \times$ Alexander $)$ plants possessing the $2 \mathrm{D}(2 \mathrm{R})$ substitution.

Two-way ANOVA demonstrated that the effects of GE on yield components were insignificant in the studied families, with the exception of GNS in $(21759 / 97 \times$ Fidelio $)$ $(\mathrm{F}=5.8 ; p=0.004)$.

\section{Germination index}

Estimation of GI in parental plants showed that Fidelio exhibited weak seed dormancy, whereas Alexander and 21759/97 exhibited pronounced after-harvest seed dormancy in 2009-2012. This is consistent with the results of a moist chamber test of preharvest sprouting resistance that was conducted in 2010 (data not shown). The GI of seeds collected from $\mathrm{F}_{2: 4}$ plants were estimated. GI was 1.04-1.80 times (significantly) lower for seeds from $\mathrm{F}_{2: 3}(21759 / 97 \times$ Fidelio) plants with the $2 \mathrm{D}(2 \mathrm{R})$ substitution than for seeds from $\mathrm{F}_{2: 3}(21759 / 97 \times$ Fidelio $)$ plants without the $2 \mathrm{D}(2 \mathrm{R})$ substitution. No significant association was found between $2 \mathrm{D}(2 \mathrm{R})$ substitution and the GI of seeds from $\mathrm{F}_{4}(21759 / 97 \times$ Fidelio $)$ and $\mathrm{F}_{2: 4}(21759 / 97 \times$ Alexander $)$ plants. Two-way ANOVA demonstrated a significant effect of environment on GI in both crosses $(p<0.001)$ and a significant effect of GE on GI only in $(21759 / 97 \times$ Fidelio $)(\mathrm{F}=5.0 ; p=0.008)$.

\section{Spike density}

Spike morphology was studied in $\mathrm{F}_{2}$ individual plants and in $\mathrm{F}_{3: 4}$ families. Spike density was significantly lower in plants with the $2 \mathrm{D}(2 \mathrm{R})$ substitution than in plants without the $2 \mathrm{D}(2 \mathrm{R})$ substitution: $\mathrm{F}_{2: 4}(21759 / 97 \times$ Fidelio $)(p<0.001)$ and $\mathrm{F}_{4}(21759 / 97 \times$ Alexander $)$ $(p=0.005)$. Environment had a significant effect on spike density in both crosses, as shown using two-way ANOVA $(p<0.001)$ : maximum spike density ( 29 spikelets per 10 $\mathrm{cm}$ of ear axis) was observed in $\mathrm{F}_{2}$, and $23-25$ spikelets per $10 \mathrm{~cm}$ were found in $\mathrm{F}_{3: 4}$. The $2 \mathrm{D}(2 \mathrm{R})$ substitution resulted in lower spike density in $(21759 / 97 \times$ Alexander $)$ on average (from 26.5 to 25 spikelets per $10 \mathrm{~cm})$, and in $(21759 / 97 \times$ Fidelio), spike density was decreased from 27 to 24 spikelets per $10 \mathrm{~cm}$ of ear axis. No significant effect of GE on spike density was observed. 
Table 2. The effect of $2 \mathrm{D}(2 \mathrm{R})$ substitution on yield components and germination index in F3-F4 populations

\begin{tabular}{|c|c|c|c|}
\hline Yield component & Year & $\begin{array}{l}\text { In plants with } 2 \mathrm{D}(2 \mathrm{R}) \\
\text { substitution }\end{array}$ & In plants without substitution \\
\hline \multicolumn{4}{|c|}{$21759 / 97 \times$ Alexander } \\
\hline \multirow[t]{2}{*}{ Grain weight per spike, $\mathrm{g}$} & 2011 & $1.0 \pm 0.2$ & $1.8 \pm 0.2 * * *$ \\
\hline & 2012 & $1.7 \pm 0.1$ & $2.7 \pm 0.2 * * *$ \\
\hline \multirow[t]{3}{*}{ Spikelet number per spike } & 2010 & $22 \pm 1$ & $29 \pm 1 * * *$ \\
\hline & 2011 & $19 \pm 1$ & $25 \pm 1 * * *$ \\
\hline & 2012 & $22 \pm 1$ & $28 \pm 1 * * *$ \\
\hline \multirow[t]{3}{*}{ Grain number per spikelet } & 2010 & $1.2 \pm 0.2$ & $1.5 \pm 0.2 * *$ \\
\hline & 2011 & $0.9 \pm 0.2$ & $1.4 \pm 0.2 * *$ \\
\hline & 2012 & $1.2 \pm 0.1$ & $1.4 \pm 0.1 * * *$ \\
\hline \multirow[t]{2}{*}{ 1000-kernel weight, g } & 2011 & $56 \pm 4$ & $50 \pm 3 *$ \\
\hline & 2012 & $66 \pm 2$ & $66 \pm 2 \mathrm{~ns}$ \\
\hline \multirow[t]{3}{*}{ Germination index } & 2010 & $0.42 \pm 0.07$ & $0.45 \pm 0.06 \mathrm{~ns}$ \\
\hline & 2011 & $0.76 \pm 0.02$ & $0.76 \pm 0.03 \mathrm{~ns}$ \\
\hline & 2012 & $0.80 \pm 0.02$ & $0.78 \pm 0.01 \mathrm{~ns}$ \\
\hline \multicolumn{4}{|c|}{$21759 / 97 \times$ Fidelio } \\
\hline \multirow[t]{2}{*}{ Grain weight per spike, $g$} & 2011 & $0.7 \pm 0.3$ & $1.8 \pm 0.3 * * *$ \\
\hline & 2012 & $1.9 \pm 0.2$ & $2.6 \pm 0.2 * * *$ \\
\hline \multirow[t]{3}{*}{ Number of spikelets per spike } & 2010 & $20 \pm 1$ & $28 \pm 1 * * *$ \\
\hline & 2011 & $18 \pm 1$ & $25 \pm 1 * * *$ \\
\hline & 2012 & $22 \pm 2$ & $27 \pm 0.5^{* * *}$ \\
\hline \multirow[t]{3}{*}{ Number of grains per spikelet } & 2010 & $1.3 \pm 0.3$ & $1.5 \pm 0.1 \mathrm{~ns}$ \\
\hline & 2011 & $0.9 \pm 0.4$ & $1.4 \pm 0.2 * *$ \\
\hline & 2012 & $1.4 \pm 0.1$ & $1.5 \pm 0.1 \mathrm{~ns}$ \\
\hline \multirow[t]{2}{*}{ 1000-kernel weight, $g$} & 2011 & $46 \pm 7$ & $48 \pm 2 \mathrm{~ns}$ \\
\hline & 2012 & $62 \pm 4$ & $64 \pm 1 \mathrm{~ns}$ \\
\hline \multirow[t]{3}{*}{ Germination index } & 2010 & $0.19 \pm 0.07$ & $0.35 \pm 0.07 * *$ \\
\hline & 2011 & $0.74 \pm 0.05$ & $0.77 \pm 0.01 *$ \\
\hline & 2012 & $0.76 \pm 0.06$ & $0.79 \pm 0.01 \mathrm{~ns}$ \\
\hline
\end{tabular}

Notes: *The difference between the means of plants with $2 \mathrm{D}(2 \mathrm{R})$ substitution and without is significant at $5 \%$ level $(p<0.05)$; **The difference between the means of plants with $2 \mathrm{D}(2 \mathrm{R})$ substitution and without is significant at $1 \%$ level $(p<0.01)$; *** The difference between the means of plants with $2 \mathrm{D}(2 \mathrm{R})$ substitution and without is significant at $0.1 \%$ level $(p<0.001)$; ns: the difference is non-significant $(p>0.05)$. 


\section{Grain plumpness}

21759/97 and Fidelio produced well-filled grain with smooth surfaces, whereas Alexander produced well-filled grain with rough surfaces. The $2 \mathrm{D}(2 \mathrm{R})$ substitution significantly reduced grain plumpness in $\mathrm{F}_{3: 4}(21759 / 97 \times$ Alexander $)$ and in $\mathrm{F}_{4}(21759 / 97 \times$ Fidelio $)$ $(p<0.01)$. Plants with complete rye genomes possessed well-filled or excellently filled grain, whereas grain from $2 \mathrm{D}(2 \mathrm{R})$ substitution plants was satisfactorily or poorly filled.

\section{Duration of development stages}

$2 \mathrm{D}(2 \mathrm{R})$ substitution did not significantly influence the duration of booting and the wax ripeness of the grain in both crosses; however, $2 \mathrm{D}(2 \mathrm{R})$ substitution significantly accelerated heading by $2-5$ days $(p<0.05)$ and significantly accelerated anthesis by $2-4$ days $(p<0.001)$. Thus, $2 \mathrm{D}(2 \mathrm{R})$ substitution tended to shorten the period from booting to heading.

\section{Discussion}

Our studies demonstrated a significant effect of $2 \mathrm{D}(2 \mathrm{R})$ chromosomal substitution on plant height in hexaploid triticale. Our results are consistent with a number of similar works, in which $2 \mathrm{D}(2 \mathrm{R})$ substitution reduced plant height in the absence of the Rht 8 gene dwarfing allele on the 2D chromosome (Budak et al. 2004; Kurkiev 2008). Tight linkage between Rht8 and the 192-bp allele at the microsatellite locus Xgwm261 has been reported, and this allele has been suggested as being diagnostic for Rht8 (Korzun et al. 1998). In our study, the 165-bp allele was detected, which is one of the most widespread alleles in wheat collections (Worland et al. 1998; Korzun et al. 1998). In our case, the reduction in plant height that resulted from the $2 \mathrm{D}(2 \mathrm{R})$ substitution might be due to genes other than Rht8, which affect plant height and are located on the $2 \mathrm{D}$ and $2 \mathrm{R}$ chromosomes.

The results demonstrate that the $2 \mathrm{D}(2 \mathrm{R})$ chromosomal substitution caused a substantial decrease in the SNS, which is apparently characteristic of all $2 \mathrm{D}(2 \mathrm{R})$ substitution triticales (Kurkiev 2008). In some cases, 2D(2R) substitution plants exhibited lower GNS. Apparently, the effect of the 2D(2R) substitution on GNS is associated with both the background genotype and weather conditions. The large 1,000-kernel weight observed for $\mathrm{F}_{3}(21759 / 97 \times$ Alexander $)$ can be explained by the low value of GNS. A similar effect of $2 \mathrm{D}(2 \mathrm{R})$ substitution has been reported previously. In a similar study, the Presto $2 \mathrm{D}(2 \mathrm{R})$ substitution line exhibited larger grain size and 1,000-kernel weight than complete Presto (Budak et al. 2004). In other cases, 2D(2R) substitution did not affect 1,000kernel weight. Thus, we can assume that under given climatic conditions, winter triticale lines with the $2 \mathrm{D}(2 \mathrm{R})$ substitution will exhibit lower yields than hexaploid triticale with a complete rye genome; however, the former plants might yield coarser grain.

GI was significantly decreased by the $2 \mathrm{D}(2 \mathrm{R})$ substitution in $\mathrm{F}_{2: 3}(21759 / 97 \times$ Fidelio). This finding is consistent with the results obtained in previous experiments (Rybka 2003). 
The association between GI and 2D(2R) substitution was not found in plants derived from the $(21759 / 97 \times$ Alexander $)$ cross. It should be noted that the $2 \mathrm{D}$ chromosome was transmitted to triticale from the same donor (21759/97) in both crosses. This result is expected because triticale and rye varieties are polymorphic regarding the genes responsible for seed dormancy and resistance to preharvest sprouting, which are located on the $2 \mathrm{R}$ chromosome (Masojć et al. 2007). Furthermore, genes located on the 2R and 2D chromosomes can interact with genes from other chromosomes.

In both crosses, the grains formed in plants containing the $2 \mathrm{D}(2 \mathrm{R})$ substitution were less plump and more shrivelled than those formed in plants without the substitution. However, the maternal line 21759/97 with the 2D(2R) substitution produced well-filled grain with smooth surfaces. The negative impact of the $2 \mathrm{D}(2 \mathrm{R})$ substitution on grain performance was demonstrated in previous studies (Reddy and Zereena 1999). At the same time, the Presto 2D(2R) substitution line does not differ substantially from Presto according to the grain test weight, a trait that indirectly reflects grain plumpness and smoothness (Budak et al. 2004). Therefore, the adverse effect of the 2D(2R) substitution can be compensated by certain gene systems that are formed by selection for grain quality. Most likely, in our experiments, the compensation system in $21759 / 97$ was disassembled in the progeny, leading to the shrivelled grain observed in plants containing the $2 \mathrm{D}(2 \mathrm{R})$ substitution.

$2 \mathrm{D}(2 \mathrm{R})$ substitution shortens the growing season of triticale somewhat and unequally influences the duration of various development stages. Previously, it was observed that the $2 \mathrm{D}(2 \mathrm{R})$ substitution reduces the period before flowering, albeit weakly (Budak et al. 2004).

The studied traits are quantitative; that is, they are determined not by major genes but by a set of genes that have minor effects. An effective breeding strategy is to search for quantitative trait loci (QTLs). Several QTLs conferring grain yield (QGyld.agt-2D), GNS (QGnu.ipk-2D, QGne.nfcri-2D.2), test weight (QTwt.crc-2D), kernel weight (QGwe.ipk2D.1, QGwe.ipk-2D.4), grain-filling (SWSCF), plant height (QHt.crc-2D) and heading date (QEet.ipk-2D) were mapped to the 2D chromosome (http://ccg.murdoch.edu.au/ cmap/ccg-live). Recently, the draft assembly of 2D chromosome sequence reads was developed and aligned with the consensus QTL map (Jia et al. 2013). Thus, further investigation of the obtained $2 \mathrm{D}(2 \mathrm{R})$ substation triticale lines might be useful for the development of molecular markers for agronomical traits that are determined by QTLs that are located on the $2 \mathrm{D}$ chromosome.

Thus, we can conclude that the $2 \mathrm{D}(2 \mathrm{R})$ substitution reduces plant height, thereby contributing to greater resistance to lodging, reduces the SNS, either does not influence the 1,000 -kernel weight or increases it, does not improve the physical properties of the grain (plumpness and smoothness), and promotes early flowering and heading in hexaploid winter triticale plants. In some years, $2 \mathrm{D}(2 \mathrm{R})$ substitution can reduce GNS. In addition, $2 \mathrm{D}(2 \mathrm{R})$ substitution in hexaploid triticale can increase preharvest sprouting resistance by increasing seed dormancy at harvest. However, 2D(2R) substitution lines are not recommended for cultivar-development purposes due to the observed decrease in grain productivity. 


\section{References}

Bernatzky, R., Tanksley, S.D. 1986. Genetics of actin-related sequences in tomato. Theor. Appl. Genet. 72:314 321.

Budak, H., Baenziger, P.S., Beecher, B.S., Graybosch, R.A., Campbell, B.T., Shipman, M.J., Erayman, M., Eskridge, K.M. 2004. The effect of introgressions of wheat D-genome chromosomes into "Presto" triticale. Euphytica 137:261-270.

Budzianowski, G., Woś, H. 2004. The effect of single D-genome chromosomes on aluminum tolerance of triticale. Euphytica 137:165-172.

Darvey, N.L., Naeem, H., Gustafson, J.P. 2000. Triticale: production and utilization. In Kulp, K., Ponte, J. (eds), Handbook of Cereal Science and Technology. 2nd ed. Marcel Dekker. New York, USA. pp. 257-274.

Divashuk, M.G., Kroupin, P.Yu., Soloviev, A.A., Karlov, G.I. 2010a. Molecular cytogenetic characterization of the spring triticale line 131/7 carrying a rye-wheat translocation. Rus. J. Genet. 46:185-190.

Divashuk, M.G., Soloviev, A.A., Karlov, G.I. 2010b. The effect of selection for phenotypical characters on the chromosome constitution in spring triticale. Rus. J. Genet. 46:340-344.

Fisher, R.A. 1934. Statistical Methods for Research Workers. Oliver and Boyd. Edinburgh, UK. pp. 99-101.

Gill, R.S., Bains, N.S., Dhindsa, G.S. 2010. Characterization of D/R chromosome segregant lines from triticale $\times$ bread wheat crosses using chromosome specific SSR markers. Wheat Inf. Serv. 110:19-23.

Gupta, P.K., Priyadarshan, P.M. 1982. Triticale: present status and future prospects. Adv. Genet. 21:255-345.

Jia, J., Zhao, S., Kong, X., Li, Y., Zhao, G., He, W. et al. 2013. Aegilops tauschii draft genome sequence reveals a gene repertoire for wheat adaptation. Nature 496:91-95.

Kim, B.Y., Baier, A.C., Somers, D.J., Gustafson, J.P. 2001. Aluminum tolerance in triticale, wheat, and rye. Euphytica 120:329-337.

Korzun, V., Röder, M.S., Ganal, M.W., Worland, A.J., Law, C.N. 1998. Genetic analysis of the dwarfing gene (Rht8) in wheat. Part I. Molecular mapping of Rht8 on the short arm of chromosome 2D of bread wheat (Triticum aestivum L.). Theor. Appl. Genet. 96:1104-1109.

Krasilova, N.M., Adonina, I.G., Silkova, O.G., Shumny, V.K. 2012. Transmission of the rye 2R chromosome in backcrosses of wheat - rye 2R(2D) substitution lines to common wheat varieties. Rus. J. Genet.: Appl. Res. 2:65-71.

Kurkiev, K.U. 2008. Inheritance of plant height in hexaploid triticales with R/D substitution. Rus. J. Gent. 44:1080-1086.

Lapin, D., Divashuk, M., Soloviev, A. 2007. The identification of D-genome in some spring triticale lines. Acta Agriculturae Serbica 12:41-50.

Lee, J.-H., Graybosch, R.A., Lee, D.J. 1994. Detection of rye chromosome 2R using the polymerase chain reaction and sequence-specific DNA primers. Genome 37:19-22.

Masojć, P., Banek-Tabor, A., Milczarski, P., Twardowska, M. 2007. QTLs for resistance to preharvest sprouting in rye (Secale cereale L.). J. Appl. Genet. 48:211-217.

Mergoum, M., Pfeiffer, W.H., Peña, R.J., Ammar, K., Rajaram, S. 2004. Triticale crop improvement: the CIMMYT programme. In: Triticale Improvement and Production. FAO. Rome, Italy. pp. 11-26.

Mergoum, M., Singh, P.K., Peña, R.J., Lozano-del Río, A.J., Cooper, K.V., Salmon, D.F., Gómez Macpherson, H. 2009. Triticale: a "new" crop with old challenges. In: Carena, M.J. (ed.), Cereals. Springer. New York, USA. pp. 1-21.

National Research Council. 1989. Triticale: a Promising Addition to the World's Cereal Grains. National Academy Press. Washington, D.C., USA. pp. 35-41.

Reddy, V.R.K., Zereena, V. 1999. Rye chromosome composition and kernel characters in hexaploid triticales. Crop. Res. 17:75-79.

Röder, M.S., Korzun, V., Wendehake, K., Plaschke, J., Tixier, M.-H., Leroy, P., Ganal, M.W. 1998. A microsatellite map of wheat. Genetics 149:2007-2023.

Royo, C., Rodriguez, A., Romagosa, I. 1993. Differential adaptation of complete and substituted triticale. Plant Breeding 111:113-119.

Rybka, K. 2003. An approach to identification of rye chromosomes affecting the pre-harvest sprouting in triticale. J. Appl. Genet. 44:491-496. 
Silkova, O.G., Kabanenko, Yu, N., Loginova, D.V. 2014. The effect of wheat - rye substitution on chromosome elimination: an analysis of univalents' behavior in wheat meiosis with dimonosomy and tetramonosomy. Rus. J. Genet. 50:245-252.

Sodkiewicz, W., Apolinarska, B., Sodkiewicz, T., Wiśniewska, H. 2011. Effect of chromosomes of the wheat D genome on traits of hexaploid substitution triticale. Cereal Res. Commun. 39:445-452.

Somers, D., Isaac, P. 2004. SSRs from the wheat microsatellite consortium. http://wheat.pw.usda.gov/ggpages/ $\mathrm{SSR} / \mathrm{WMC} /$

Song, Q.J., Shi, J.R., Singh, S., Fickus, E.W., Costa, J.M., Lewis, J., Gill, B.S., Ward, R., Cregan, P.B. 2005. Development and mapping of microsatellite (SSR) markers in wheat. Theor. Appl. Genet. 110:550-560. Worland, A.J., Korzun, V., Ganal, M.W., Roder, M., Law, C.N. 1998. Genetic analysis of the dwarfing gene Rht8 in wheat. Part II. The distribution and adaptive significance of allelic variants at the Rht 8 locus of wheat as revealed by microsatellite screening. Theor. Appl. Genet. 96:1110-1120. 